\title{
PENGEMBANGAN DAN PEMBERDAYAAN MASYARAKAT DALAM BENTUK PENINGKATAN KAPASISTAS MASYARAKAT DESA/KELURAHAN BERBASIS PRODUK INOVASI DALAM PENANGGULANGAN COVID-19 DI SULAWESI TENGGARA
}

${ }^{1}$ Yunus, 2 Zalili Sailan, ${ }^{3}$ La Ode Balawa, ${ }^{4}$ Irianto Ibrahim

${ }^{1234}$ Universitas Halu Oleo

Email: yunuspbsi@gmail.com

\section{RINGKASAN}

Tujan pengabdian masyarakat ini adalah memberikan pengalaman/pengetahuan baru bagi masyarakat untuk memahami pentingnya Penangulangan Covid-19 di Sulawesi Tenggara; membantu masyarakat dalam pengembangan kecakapan dalam menghasilkan produk inovasi dalam upaya Penangulangan Covid-19 di Sulawesi Tenggara; memberikan pengalaman/pengetahuan baru bagi masyarakat Desa/Kelurahan tentang pentingnya suasana hidup sehat dan segar, sehingga dapat melaksanakan segala tugas-tugas rutin dengan baik tanpa mengalamami kelelahan yang berarti, khususnya dalam upaya penangulangan Covid-19 di Sulawesi Tenggara; melatih kelompok-kelompok masyarakat sehingga mereka dapat mengembangkan diri mencapai hidup sehat dan segar sejahtera lahir batin melalui aktifitas olahraga dan penciptaan produk inovasi yang bermanfaat. Metode pelaksanaan KKN tematik ini secara tekhnis melalui pengorganisasian jarak jauh dengan menggunakan berbagai fasilitas media dan teknologi informasi. Kegiatan Pengabdian masyarakat ini dilaksanakan selama satu (1) bulan dengan luaran yang: a) Menghasilkan masker kesehatan yang bermanfaat untuk program pencegahan COVID-19 per kelompok desa; b) Membantu penyemprotan disinfektan di desa/kelurahan lokasi KKN; c) Menjadi sukarelawan di POSKO SATGAS COVID-19 selama pelaksanaan KKN Tematik dalam penyaluran bantuan pemerintah kepada masyarakat; d) Membantu distribusi masker bagi masyarakat yang terdampak COVID-19 di desa pelaksanaan KKN Tematik; e) membantu pemerintah dalam mensosialisasikan tangap pencegahan Covid-19; f) membantu masyarakat dalam proses pembutan Jamu dan Teh Kelor; g) Membantu masyarakat dalam penyediaan Pembuatan medi/alat cuci tangan, Pembuatan handsanitiser.

\section{Kata kunci: pemberdayaan; peningkatan kapasitas; masyarakat; produk inovasi; Covid-19}

\section{A. Analisis Situasi}

Dalam UU No. 6/2014 tentang Desa, pendekatan tersebut diantaranya tercermin pada tujuan pembangunan dan prioritas program yang ditujukan bagi peningkatan kesejahteraan masyarakat, kualitas hidup manusia serta penanggulangan kemiskinan, serta keterlibatan masyarakat dalam seluruh proses pembangunan desa (perencanaan, pelaksanaan, dan pengawasan). Dengan demikian pembangunan desa merupakan upaya 
memperkuat masyarakat desa sebagai subjek pembangunan. Inilah esensi dari pendekatan people centered-development dalam pembangunan desa.

Kuliah Kerja Nyata (KKN) Reguler Edisi Covid-19 tahun akademik 2019/2020 ini dirancang khusus sebagai solusi pelaksanaan KKN selama masa COVID-19. KKN ini dirancang dengan tema "KKN berbasis Produk Karya Pengabdian" yaitu KKN yang program kerja mahasiswa selama pelaksanaan adalah menciptakan produk-produk yang dapat dimanfaatkan atau dapat mengedukasi masyarakat sasaran, namun produk karya pengabdian dapat pula dikompensasikan dengan program kerja yang bersifat layanan kemasyarakatan.

Kuliah Kerja Nyata berupa kuliah pengabdian kepada masyarakat yang diselenggarakan oleh mahasiswa dengan bimbingan dosen terkait pengembangan/ pemberdayaan masyarakat dalam bentuk pembuatan produk karya pengabdian yang dipersiapkan bagi peningkatan kapasistas masyarakat desa/kelurahan di wilayah dimana mahasiswa berasal (di wilayah tempat tinggal mahasiswa masing-masing) KKN Pulang Kampung berbasis Produk Karya Pengabdian diharapkan mahasiswa dapat memberikan/menuangkan ide kreatifnya sesuai dengan potensi desa yang dimiliki. Peserta KKN Reguler ini meliputi mahasiswa dari berbagai jurusan/ multidisplin ilmu. Selama masa KKN, Mahasiswa tidak diperbolehkan tinggal di desa sampai menunggu redanya masalah penyebaran virus COVID-19, namun mahasiswa diwajibkan tetap produktif menciptakan produk inovasi bagi masyarakat.

Dari berbagai bentuk pembelajaran berwawasan kemasyarakatan, maka yang menjadi focus atau bentuk program pengabdian dosen yang terintegrasi dalam KKN Tematik ini terdiri dari dua program kegiatan. Pendidikan life skill. Pendidikan berorientasi life skill diberikan kepada masyarakat adalah sebagai bekal dalam menghadapi dan memecahkan masalah dan tantangan kehidupan yang semakin kompleks baik sebagai kehidupan pribadi yang mandiri, warga masyarakat, maupun sebagai warga negara khusus sebagai solusi pelaksanaan KKN selama masa COVID-19. Dengan demikian, pendidikan life skill adalah kemampuan dan keberanian untuk menghadapi problema kehidupan yang dilakukan secara proaktif dan kreatif mencari dan menemukan solusi 
untuk mengatasinya. Selain itu, Anwar (2004) mengatakan bahwa life skill adalah pendidikan yang dapat memberikan bekal ketrampilan yang praktis terpakai, terkait dengan kebutuhan pasar kerja, peluang usaha dan potensi ekonomi atau industri yang ada di masyarakat.

Secara spesifik, bentuk program life skillyang diberikan pada warga atau kelompok masyarakat khususnya di Desa/Kelurahan di Sulawesi Tenggara adalah memanfaatkan potensi sumber daya alam yang ada di lingkungan sekitar menjadi sebuah peluang khusus sebagai solusi dalam penganggulangan COVID-19 dengan menanamkan pengetahuan dan keterampilan. Adapun tujuan pendidikan life skill secara khusus bila dirinci adalah sebagai berikut: (a) Melaksanakan program-program pendidikan dan pelatihan yang mampu mengembangkan ketrampilan, keahlian dan kecakapan serta nilai-nilai keprofesian untuk mendorong produktivitas sebagai tenaga kerja yang handal atau kemandirian berusaha. (b) Memberikan kesempatan kepada masyarakat untuk mengikuti program khusus berbasis kompetensi, serta fasilitasi penempatan kerja pada dunia usaha/industri dan atau berusaha mandiri.

Metode

Program KKN-Tematik dengan tema "Pengembangan dan Pemberdayaan Masyarakat dalam Bentuk Peningkatan Kapasistas Masyarakat Desa/Kelurahan Berbasis Produk Inovasi dalam Penanggulangan Covid-19 Di

Sulawesi Tenggara. Hal ini merupakan kontribusi nyata bagi mahasiswa dalam menghadapi dan mencegah penyebaran wabah viruscorona covid-19 di lingkungannya. Dengan demikian peserta KKN Tematik ini tersebar pada beberapa desa di Sultra, Kususnya di Kota Kendari, Kab. Konawe Selatan, Kab. Konawe, dan Kab. Muna. Proses pelaksanaan secara tekhnis melalui pengorganisasian jarak jauh dengan menggunakan berbagai fasilitas media dan teknologi informasi. 


\section{Persiapan atau Rekruitmen Peserta}

Persiapan atau rekruitmen peserta merupakan langkah awal dalam pelaksanan kegiatan KKN-Tematik ini. Mahasiswa sebagai peserta KKN wajib untuk memprogramkan mata kuliah KKN secara online. Peserta KKN-Tematik ini adalah mahasiswa Fakultas Keguruan dan Ilmu Pendidikan dengan latar belakang Jurusan Pend. Bahasa dan Sastra Inbdonesia. Mahasiswa peserta KKN-Tematik ini adalah sebanyak 10 orang.

\section{Pembekalan Mahasiswa}

Setelah dilakukan rekruitmen, maka langkah selanjutnya yang dilakukan adalah pembekalan terhadap mahasiswa yang seluruhnya dilakukan via zoom/google meeting. Secara umum langkah-langkah pembekalan terhadap mahasiswa dalam kegiatan KKNTematik ini, diuraikan sebagai berikut:

a) Penyajian materi. Materi disampaikan oleh Dosen Pembimbing Lapangan kepada mahasiswa peserta KKN-Tematik. Materi ini berisikan tentang konsep dan masalah viruscorona covid-19, bentuk-bentuk partisipasi dalam kondisi wabah, penggunaan IT dan media informasi, desain psoter kampanye berbasis lokal, dan pembelajaran berasis IT/daring.

b) Perkenalan Program Pemberdayaan/partisipasi. Tahapan ini adalah lanjutan dari uraian materi. Peserta disajikan dengan diperkenalkan berbagai program pemberdayaan dan atau jenis kegiatan-kegiatan yang dilakukan dalam upaya pencegan covid-19 yang dapat dikembangkan oleh peserta KKN.

c) Menyiapkan Alat dan Bahan. Pada tahapan ini merupakan langkah dimana mahasiswa menyiapkan alat dan bahan sesuai dengan kondisi dilingkungan mahasiswa di lingkungan/desanya masing-masing.

d) Evaluasi Kelengkapan dan Kesiapan Pelaksanaan Program. Tahapan ini merupakan evaluasi persiapan dalam tahapan pembekalan mahasiswa; kondisi jaringan di lokasi tempat domisili mahasiswa, ketersediaan pulsa/paket, penerimaan dan interkasi dengan masyarakat. 


\section{Pelaksanaan}

Tahapan atau prosedur pelaksanaan kegiatan KKN-Tematik ini dilakukan dengan empat (4) tahapan (action research) yaitu: perencanaan, tindakan, observasi dan evaluasi/refleksi. Masing-masing tahapan dijelaskan sebagai berikut:

a) Perencanaan

Tahapan perencanaan terdiri atas:

(1) Analisis kebutuhan dan Pemetaan Kondisi.

Tahapan ini dilakukan untuk mengidentifikasi dan mengumpulkan informasi awal mengenai program pemberdayaan yang dikembangkan.

(2) Sosialisasi program KKN-Tematik pada khalayak sasaran

Sosialisasi dilakukan untuk mengkomunikasikan program KKN-Tematik oleh masing-masing mahasiswa secara terbatas pada kepala desa, RT, dan tokoh-tokoh kunci dilingkungannya.

(3) Penyusunan Program

Setelah dilakukan identifikasi/analisis kebutuhan dan sosialisasi program yang dilaksanakan, maka tahapan selanjutnya adalah menyusun program kegiatan partisipasi pada pencegahan Covid-19.

b) Tindakan/Implementasi Program

Tindakan yang dimaksud dalam program KKN-Tematik ini adalah implementasi program. Program yang dilakukan mengacu pada langkah-langkah program pemberdayaan masyarakat, sesuai dengan perencanaan, tindakan aksi partisipasi pada pencegahan Covid-19.

c) Observasi dan Evaluasi

Observasi dilakukan terhadap proses pelaksanaan program pemberdayaan. Dengan menggunakan lembar pengamatan, beberapa hal yang perlu diobservasi adalah berupa 
kendala-kendala, dan kelemahan yang ada selama proses pelaksanaan pemberdayaan. Sedangkan evaluasi dilakukan terhadap kualitas pelaksanaan program. Semua meggunakan instrumen yang di share melalui file dan media Informasi pada mehasiswa.

d) Refleksi

Refleksi dilakukan terhadap seluruh rangkaian atau tahapan kegiatan yang telah dilaksanakan mahasiswa di tengah kondisi wabah dan tanggap darurat. Pada refleksi ini juga untuk merumuskan tindak lanjut pada masyarakat.

\section{Pembahasan}

Pengabdian Kepada Masyarakat yang terintegrasi dengan KKN Tematik yang dilaksanakan pada tahun akademik 2019/2020 dengan tema "Pengembangan dan Pemberdayaan Masyarakat dalam Bentuk Peningkatan Kapasistas Masyarakat Desa/Kelurahan Berbasis Penanggulangan Covid-19 Di Sulawesi Tenggara. Pengabdian ini dilaksanakan sebagai wujud tanggung jawab warga Negara, khususnya mahasiswa dalam menghadapi dan mencegah penyebaran wabah Covid-19 di lingkungann dan di daerahnya masing-masing.

KKN Tematik Covid-19 Universitas Halu Oleo tahun 2020 berlangsung sejak 12 Juni s.d. 12 Juli 2020. KKN Tematik Covid-19 kelompok 17 dari Jurusan Pend. Bahasa dan Sastra Indonesia FKIP UHO terdiri atas 10 orang mahasiswa yang tersebar di empat Kabupaten/Kota di Sulawesi Tenggara, yaitu Kota Kendari, Kab. Konawe Selatan, Kab. Konawe, dan Kabupaten Muna.

Melalui kegiatan KKN Tematik ini diharapkan dapat memberikan pengalaman/pengetahuan baru bagi masyarakat untuk memahami pentingnya Penangulangan Covid-19 di Sulawesi Tenggara; dan memberikan pengalaman/pengetahuan baru bagi masyarakat Desa/Kelurahan tentang pentingnya suasana hidup sehat dan segar, sehingga dapat melaksanakan segala tugas-tugas rutin 
dengan baik tanpa mengalamami kendala yang berarti, khususnya dalam upaya penangulangan Covid-19 di Sulawesi Tenggara; serta melatih kelompok-kelompok masyarakat sehingga mereka dapat mengembangkan diri mencapai hidup sehat dan sejahtera lahir batin melalui aktivitas yang bermanfaat.

\section{Sosialisasi Pencegahan Covid 19}

Coronavirus Disease 2019 (COVID-19) adalah penyakit menular yang disebabkan oleh Severe Acute Respiratory Syndrome Coronavirus 2 (SARSCoV-2). SARS-CoV-2 merupakan coronavirus jenis baru yang belum pernah diidentifikasi sebelumnya pada manusia. Ada setidaknya dua jenis coronavirus yang diketahui menyebabkan penyakit yang dapat menimbulkan gejala berat seperti Middle East Respiratory Syndrome (MERS) dan Severe Acute Respiratory Syndrome (SARS). Tanda dan gejala umum infeksi COVID19 antara lain gejala gangguan pernapasan akut seperti demam, batuk dan sesak napas. Masa inkubasi rata-rata 5-6 hari dengan masa inkubasi terpanjang 14 hari. Pada kasus COVID-19 yang berat dapat menyebabkan pneumonia, sindrom pernapasan akut, gagal ginjal, dan bahkan kematian.

Dilihat dari situasi penyebaran COVID-19 yang sudah hampir menjangkau seluruh wilayah provinsi di Indonesia dengan jumlah kasus dan/atau jumlah kematian semakin meningkat dan berdampak pada aspek politik, ekonomi, sosial, budaya, pertahanan dan keamanan, serta kesejahteraan masyarakat di Indonesia, Pemerintah Indonesia telah menetapkan Keputusan Presiden Nomor 11 Tahun 2020 tentang Penetapan Kedaruratan Kesehatan Masyarakat Corona Virus Disease 2019 (COVID-19). Keputusan Presiden tersebut menetapkan COVID-19 sebagai jenis penyakit yang menimbulkan Kedaruratan Kesehatan Masyarakat (KKM) dan menetapkan KKM COVID-19 di Indonesia yang wajib dilakukan upaya penanggulangan sesuai ketentuan peraturan perundang-undangan. Selain itu, atas pertimbangan penyebaran COVID19 berdampak pada meningkatnya jumlah korban dan kerugian harta benda, meluasnya cakupan wilayah terdampak, serta menimbulkan implikasi pada aspek sosial ekonomi yang luas di Indonesia, telah dikeluarkan juga Keputusan Presiden Nomor 12 Tahun 2020 tentang Penetapan Bencana Nonalam Penyebaran Corona Virus Disease 2019 (COVID-19) Sebagai Bencana Nasional. 


\section{a. Pencapaian Program}

Program ini berjalan dengan lancar dimana sosialisasi dilaksanakan dalam waktu yang berbeda sesuai dengan hasil komunikasi antar peserta KKN Tematik dangan pihak pemerintah setempat. Secara Jangka Pendek : Meningkatkan pemahaman masyarakat tentang pentingnya memahami cara penanggulangan Covid 19. Secara Jangka Panjang : Menanamkan semangat giat memerangi Covid 19 dalam kehidupan sehari hari.

\section{b. Kendala}

Di wilayah Konawe selatan dengan Jumlah warga masyarakat yang sangat antusias sedangkan ruangan yang digunakan sebagai tempat sosialisasi kurang luas sehingga suasana kurang kondusif dan untuk wilayah lain jumlah masyarakat yang ikut dalam program sosialisasi belum maksimal karena mereka lebih memilih untuk tinggal di rumah. Bagi wilayah dan daerah tertentu, bentuk sosialisasi dilaksanakan dengan menempelkan berupa stiker kesehatan yang berisi ajakan dan mencegah covid-19 dengan panduan cuci tangan,memakai handsanitiser, penggunaan masker,rajin minum air putih.

\section{c. Tindak Lanjut}

Perlu kontrol dari pihak pemerintah setempat dalam kegiatan bimbingan dan sosialisasi yang terus menerus kepada warga. Pemerintah Desa/Kelurahan dapat pula melanjutkan dan meningkatkan program ini bagi warga dilingkungan masingmasing.

\section{Penyemprotan Cairan Desinfektan}

Untuk meminimalisir risiko penyebaran covid-19 yang dapat menular antarmanusia, berbagai cara dilakukan. Salah satunya ialah menyemprotkan cairan desinfektan. Disinfektan adalah bahan kimia seperti lisol, kreolin, yang digunakan untuk mencegah terjadinya pencemaran jasad resik. Disinfektan merupakan cara menghilangkan atau membunuh segala hal terkait mikroorganisme baik virus maupun bakteri, pada objek permukaan benda mati. 
a) Penyemprotan disinfektan untuk menangkal virus corona (Covid 19) giat dilakukan pemerintah dan juga secara mandiri oleh masyarakat.

b) Disinfektan merupakan cara menghilangkan atau membunuh segala hal terkait mikroorganisme baik virus maupun bakteri, pada objek permukaan benda mati. Bahan disinfektan berbeda dengan antiseptik baik secara tujuan, dosis, dan teknik yang digunakan.

c) Disinfektan alami bisa kita buat sendiri di rumah dari bahan yang ada. Cara membuatnya tidak sulit. Siapkan setengah cangkir cuka putih [suling], setengah gelas air, lalu 12-24 tetes minyak esensial [kemangi, kayu manis, cengkih, kayu putih, dan jeruk nipis].

d) Selain disinfektan, ada langkah sederhana untuk memutus rantai penyebaran virus corona. Caranya, melalui aspek protektif personal yakni cuci tangan. Cuci tangan bisa menggunakan hand sanitizer alami.

\section{a. Pencapaian Program}

Program ini berjalan dengan lancar pada setiap lokasi yang berdeda. Hal ini disebabkan karena dukungan warga dan pemerintah daerah setempat. Secara Jangka Pendek : Meningkatkan pemahaman masyarakat tentang pentingnya memahami cara penanggulangan Covid 19 melalui program penyemprotan disenfektan. Secara Jangka Panjang : Menanamkan semangat dan perhatian dalam penanggulangan Covid 19 dalam kehidupan sehari hari.

\section{b. Kendala}

Kendala yang dihadapai dalam program penyemprotan disenfektan, masih ada sebagain masyarakat yang tidak mengiginkan rumah dan sekitarnya untuk penyemprotan. Hal ini disebabkan karena pemahaman masyarakat tentang pentingnya penyemprotan disinfektan masih kuran dan sosialisasi penanggulangan Covid 19 belum dilaksanakan secara menyeluruh.

\section{c. Tindak Lanjut}


Perlu kontrol dari pihak pemerintah setempat dalam penanaman pemahanan tentang pentingnya penyemprotan disinfektan sebagai salah satu cara penanggulangan Covid 19. Pemerintah Desa/Kelurahan dapat pula melanjutkan dan meningkatkan program ini bagi warga dilingkungan masing-masing.

\section{Pembuatan Jamu dan Teh Kelor}

Rempah-rempah bukan hanya bisa digunakan sebagai bumbu masakan saja. Di balik khasiatnya yang membuat rasa masakan lebih sedap, rempah juga memiliki manfaat untuk kesehatan. Beberapa rempah bahkan bisa dimanfaatkan untuk menjaga sistem imun. Rempah tersebut kaya akan antioksidan, yang mampu menjaga tubuh dari serangan radikal bebas penyebab berbagai macam penyakit.

Apalagi saat ini kita sangat membutuhkan asupan yang bersifat imunomodulator (bisa meningkatkan sistem imun). Salah satu sifat asupan seperti ini bisa ditemukan dalam rempah-rempah. Bumbu dapur itu bisa kamu gunakan untuk dijadikan minuman sehat di rumah. Khususnya dalam penaggulangan Covid 19, Peserta KKN Tematik bersama warga masyarakan di Kab. Konawe Selatan dan Kab. Muna melatih masyarakat dalam pembuatan Jamu dan Teh Kelor.

\section{a. Pencapaian Program}

Program pembuatan Jamu dan Teh Kewlor berjalan dengan lancar pada setiap lokasi yang berdeda. Hal ini disebabkan karena dukungan warga dan pemerintah daerah setempat di dua lokasi tersebut sangat baik. Secara Jangka Pendek : Meningkatkan pemahaman masyarakat tentang pentingnya memahami cara penanggulangan Covid 19 dengan meningkatkan kekebalan tubuh dan daya imun yang baik melalui program pembuatan/konsumsi Jamu dan Teh Kelor yang kontinyu. Secara Jangka Panjang : Menanamkan pemahaman dan perhatian dalam penanggulangan Covid 19 dalam kehidupan sehari hari.

\section{b. Kendala}

Kendala yang dihadapai dalam program pembuatan Jamu dan Teh Kelor, adalah masih ada sebagain masyarakat yang tidak suka minum jamu dan Teh Kelor 
karena faktor kebiasaan, sehingga mereka tidak serius dalam mengikuti setiap tahapan-tahapan pembuatan jamu dan Teh kelor tersebut.

\section{c. Tindak Lanjut}

Perlu kontrol dari pihak pemerintah setempat dalam penanaman pemahanan tentang pentingnya meningkatkan daya tahan tubuh dan imin dengan mengkonsumsi Jamu dan Teh Kelor sebagai produk lokal untuk penanggulangan Covid 19. Pemerintah Desa/Kelurahan dapat pula melanjutkan dan meningkatkan program ini bagi warga dilingkungan masing-masing.

\section{Pembuatan Masker dengan Memanfaatkan Bahan Disekitar}

Pandemi COVID-19 memang sangat menakutkan. Jadi, kita diharukan mengusahakan segala sesuatu untuk menjaga kesehatan. Sebagai langkah pencegahan, kita dihapkan memakai masker medis untuk melindungi diri dari virus. Untungnya, dengan keterampilan menjahit dasar saja, Anda bisa membuat masker kain sendiri dengan mudah di rumah. Meskipun begitu, perlu Anda ingat bahwa masker ini tidak seefektif masker medis/bedah. Jadi, sebaiknya masker ini hanya dipakai jika Anda tidak punya pilihan lain.

\section{Pilihlah kain yang tebal dan rapat untuk kedua lapisan masker. Anda} membutuhkan 2 lapis kain untuk membuat masker yang lebih efektif. Untuk hasil terbaik, pilihlah kain yang lebih tebal untuk lapisan luar, dan kain katun yang lebih tipis untuk lapisan dalam.

- Berdasarkan penelitian baru-baru ini, bahan yang paling bagus untuk masker kain rumahan adalah kain steril pembungkus peralatan bedah. Kain ini dapat menahan 99\% kuman dan partikulat.

- Sementara itu, untuk lapisan luar masker, Anda bisa menggunakan kain nonelastis seperti denim, kain kepar (twill), kanvas, kain duck, atau kain quilting.

- Untuk lapisan dalam, Anda bisa menggunakan kain katun atau campuran katun, asalkan nonelastis. 
Gunakan kain kaus katun $\mathbf{1 0 0 \%}$ yang stabil. Anda mungkin tidak punya kain di rumah dan tidak ingin pergi ke toko kain. Untungnya, Anda bisa memanfaatkan kaus lama untuk membuat masker. Cukup rebus kaus dengan sepanci air selama 10 menit untuk mensterilkan dan mengerutkan ukurannya. Setelah itu, jemur hingga kering.

- Untuk hasil terbaik, pilihlah kaus seperti Hanes Heavyweight $100 \%$ preshrunk cotton. Atau, manfaatkan kaus lama apa saja yang tersedia di rumah.

Manfaatkan sarung bantal lama jika tidak ada kaus. Meskipun bukan pilihan ideal, kain sarung bantal masih bisa melindungi Anda dari kuman. Manfaatkan kain sarung bantal jika hanya pilihan ini yang Anda punya.

- Kain kaus umumnya bisa lebih melindungi daripada kain sarung bantal. Jadi, jika ada, jadikan kaus sebagai pilihan pertama.

\section{Pasangkan warna dan motif berbeda sehingga Anda mudah mengenali bagian}

depan masker. Memakai masker secara terbalik justru bisa membuat Anda terpapar kuman yang ingin dihindari. Untuk memudahkan Anda mengenali sisi depan dan belakang masker, padukan warna atau motif berbeda pada paling tidak salah satu sisinya.

\section{a. Pencapaian Program}

Program ini berjalan dengan lancar. Hal ini disebabkan karena dukungan warga dan pemerintah daerah setempat. Secara Jangka Pendek : Meningkatkan pemahaman masyarakat tentang pentingnya menggunakan masker sebagai salat satu cara penanggulangan Covid 19. Secara Jangka Panjang : Menanamkan semangat dan perhatian dalam penanggulangan Covid 19 dalam kehidupan sehari hari.

\section{b. Kendala}

Kendala yang dihadapai dalam program pembuatan masker, masih ada sebagain masyarakat yang tidak tertarik untuk belajar membuat masker. Hal ini disebabkan karena selain pemahaman masyarakat tentang pentingnya menggunakan dan membat masker masih kuran, juga disebabkan belum ada kesadaran yang baik tentang pentingnya menggunakan masker dalam kehidupan sehari-hari. 


\section{c. Tindak Lanjut}

Perlu kontrol dari pihak pemerintah setempat dalam penanaman pemahanan tentang pentingnya memiliki keterampilan dalam membuat masker sebagai antisipasi masyarakat dalam menghadapi kelangkaan masker di masyarakat.

\section{Pembagian Masker}

Virus Corona Covid-2019 sejak awal tahun ini memang menjadi perhatian banyak orang. Pasalnya, kasus virus Corona hingga saat ini sudah menewaskan lebih dari ribuan bahkan ratusan ribu orang di seluruh dunia. dengan jumlah total kasus terkonfirmasi yang terus bertambah. Berbagai negara telah menerapkan darurat medis untuk mencegah penyebaran virus Corona di negara mereka. Di Indonesia sendiri sudah dilakukan tindakan pencegahan penyebaran virus Corona oleh Kementerian Kesehatan. Salah satu upaya pencegahan penularan penyakit adalah dengan menggunakan masker, tetapi masyarakat sebelumnya perlu mengetahui bagaimana cara memakai masker yang benar.

Hal ini tentu saja bertujuan untuk meminimalisir penyebaran virus serta melindungi diri dari penyakit termasuk salah satunya juga mencegah penyakit dari virus Corona. Lalu bagaimanakah cara menggunakan masker dengan benar?

1. Menutup mulut, hidung dan dagu anda. Pastikan bagian masker yang berwarna berada di sebelah depan

2. Tekan bagian atas masker supaya mengikuti bentuk hidung Anda dan tarik ke belakang ke bagian bawah dagu.

3. Lepas masker yang telah digunakan dengan hanya memegang tali dan langsung buang ke tempat sampah tertutup

4. Cuci tangan pakai sabun setelah membuang masker yang telah digunakan ke dalam tempat sampah.

5. Biar bersih, ganti masker anda secara rutin apabila kotor atau basah.

\section{a. Pencapaian Program}


Program ini berjalan dengan lancar pada setiap lokasi yang berdeda. Hal ini disebabkan karena dukungan warga dan pemerintah daerah setempat. Secara Jangka Pendek: Meningkatkan pemahaman masyarakat tentang pentingnya memahami cara penanggulangan Covid 19 melalui program pemakaian masker kesehatan yang benar sesuai protokol kesehatan. Secara Jangka Panjang : Menanamkan pemahaman dan perhatian menggunakan masker kesehatan dalam penanggulangan Covid 19 dalam kehidupan sehari hari.

\section{b. Kendala}

Kendala yang dihadapai dalam program pembagian masker, masih ada sebagain masyarakat yang menerima masker pembagian tetapi hanya disimpan dan tidak digunakan sebagai mana mestinya. Hal ini disebabkan karena pemahaman masyarakat tentang pentingnya penggunaan masker masih kuran dan sosialisasi penanggulangan Covid 19 belum dilaksanakan secara menyeluruh dan berkesinambungan.

\section{c. Tindak Lanjut}

Perlu kontrol dari pihak pemerintah setempat dalam penanaman pemahanan tentang pentingnya penggunaan masker kesehatan sebagai salah satu cara penanggulangan Covid 19. Pemerintah Desa/Kelurahan dapat pula melanjutkan dan meningkatkan program ini bagi warga dilingkungan masing-masing.

\section{Pembuatan Media/Alat Cuci Tangan}

Ditengah pandemi Covid-19 kita harus selalu patuhi protokol kesehatan. Faktor paling menyumbang kasus positif adalah ketidak disiplinan mencuci tangan. Karena mencuci tangan adalah hal yang wajib untuk kita terapkan dimasa pandemi ini guna pencegahan Covid-19, dengan kebiasaan mencuci tangan dapat mengurangi sepertiga dari resiko terinfeksi covid-19, dengan rutin mencuci tangan akan membantu melindungi diri kita dari virus yang tersebar dari orang yang ada disekitar kita. Tanpa kamu sadari langkah sederhana seperti ini dapat membantu menjaga tingkat infeksi rendah dan mengurangi penularan virus corona. 


\section{a. Pencapaian Program}

Program ini berjalan dengan lancar pada setiap lokasi yang berdeda. Hal ini disebabkan karena dukungan warga dan pemerintah daerah setempat yang baik. Secara Jangka Pendek : Meningkatkan pemahaman masyarakat tentang pentingnya memahami cara penanggulangan Covid 19 melalui program mencuci tangan yang benar sesuai protokol kesehatan. Secara Jangka Panjang : Menanamkan pemahaman dan perhatian masyarakat dalam membiasakan diri mencuci tangan dengan benar sebagai bagian dalam penanggulangan Covid 19 dalam kehidupan sehari hari.

\section{b. Kendala}

Kendala yang dihadapai dalam program pembuatan alat/media cuci tangan, masih ada sebagain masyarakat yang belum berperan aktif dalam menyiapkan media/alat tersebut. kendala lain berkaitan dengan biaya pengadaan media (ember ukuran besar dan kelengkapannya) sehingga harus mengeluarkan uang tambahan. Hal ini disebabkan karena pemahaman masyarakat tentang pentingnya mencuci tangan sesuai protokol kesehatan masih kuran dan sosialisasi penanggulangan Covid 19 belum dilaksanakan secara menyeluruh dan berkesinambungan.

\section{c. Tindak Lanjut}

Perlu kontrol dari pihak pemerintah setempat dalam penanaman pemahanan tentang pentingnya mencuci tangan dengan menggunakan sabun sesuai dengan protokol kesehatan sebagai salah satu cara penanggulangan Covid 19. Pemerintah Desa/Kelurahan dapat pula melanjutkan dan meningkatkan program ini bagi warga dilingkungan masing-masing.

\section{Pembuatan Handsanitiser}

Hand sanitizer (gel pembersih tangan) merupakan gel yang memiliki kandungan antibakteri dalam menghambat hingga membunuh bakteri. Penambahan 
bahan antibakteri dan bahan aktif perlu diperhatikan agar tidak menimbulkan iritasi pada kulit dan tidak menimbulkan alergi. Ekstrak daun sirih mengandung saponin, tanin, dan flavanoid yang dapat menghambat pertumbuhan bakteri Stephylococcus aureus.

Daun sirih kering dimaserasi selama $3 \times 24$ jam dengan pergantian pelarut setiap harinya, selanjutnya diperas hingga diperoleh filtrat. Filtrat kemudian diuapkan untuk menghilangkan kandungan alkohol dengan menggunakan vacuum evaporator pada suhu $60 \mathrm{oC}$ hingga volumenya berkurang $80 \%$. Ekstrak daun sirih kemudian diolah menjadi produk gel hand sanitizer. Dalam proses pembuatan hand sanitizer, carbomer (gelling agent) dilarutkan dengan aquadest yang dipanaskan pada suhu $800 \mathrm{C}$. Setelah carbomer larut, suhu diturunkan menjadi $30 \mathrm{oC}$ dan dilakukan penambahan Triethanolamine/TEA (alkalizing agent) sambil diaduk hingga membetuk gel yang bening. Selanjutnya, dilakukan penambahan Gliserol (humektan), Propilen Glikol (stabilizer), Nipagin (pengawet), ekstrak daun sirih dan diakhiri dengan penambahan essensial oil.

Pada bagian lain, Organisasi kesehatan dunia (WHO) telah merilis sebuah panduan tentang cara membuat hand sanitizer untuk produksi rumahan yang dapat kita ikuti. Di dalam panduan tersebut tercantum resep, cara pembuatan, dan anjuran menggunakan hand sanitizer dengan benar.

Terdapat dua resep hand sanitizer dalam panduan dari WHO ini. Resep pertama menggunakan ethanol 96 persen dan resep kedua menggunakan isopropil alkohol 99,8 persen. Berikut uraiannya.

\section{Resep 1:}

Hand Sanitizer dengan Bahan Ethanol 96 persen. Untuk hasil akhir hand sanitizer sebanyak 1 liter, berikut bahan-bahan yang diperlukan: Ethanol 96\% sebanyak $833 \mathrm{ml}$, Gliserin sebanyak14,5ml; Hidrogen peroksida sebanyak 41,7 ml Air suling steril (distilasi) atau air minum yang direbus ditambahkan hingga larutan mencapai 1 liter (sekitar $110 \mathrm{ml}$ atau hingga mencapai batas 1 liter pada gelas ukur).

\section{Resep 2:}


Hand Sanitizer dengan Bahan Isopropil Alkohol 99,8 Persen. Untuk hasil akhir handsanitizer sebanyak 1 liter. Isopropil alkohol 99,8\% sebanyak 751,5 ml Gliserin sebanyak14,5ml; Hidrogen peroksida sebanyak 41,7 ml. Air suling atau air minum yang direbus ditambahkan hingga larutan mencapai 1 liter (sekitar $192 \mathrm{ml}$ atau hingga mencapai batas 1 liter pada gelas ukur).

Bahan-bahan tersebut tersedia di apotek atau toko bahan kimia. Jika Anda membelinya di toko bahan kimia, siapkan fotokopi kartu identitas Anda karena pihak toko biasanya akan memintanya. Berbagai bahan di atas biasanya tersedia dalam ukuran masing-masing 1 liter. Jika tersisa banyak, dapat Anda simpan untuk pembuatan selanjutnya.

\section{Alat-Alat yang Diperlukan untuk Kedua Resep}

Berikut alat-alat yang perlu dipersiapkan sebagai cara membuat hand sanitizer:
a. Gelasukur

b. Corong

c. Jerigen/botol bersih berukuran 1 liter untuk mencampur semua bahan d. Botol plastik spray ukuran $50 \mathrm{ml}$ atau $100 \mathrm{ml}$ untuk membagi hand sanitizer yang sudah jadi.

\section{Langkah-Langkah Pembuatan Hand Sanitizer}

Langkah-langkah di bawah ini perlu diikuti secara rinci agar hasil yang diharapkan sesuai dengan standar panduan dari WHO a) Ukur semua bahan sesuai dengan takarannya; b) Pertama masukan ethanol atau isopropil alkohol pada jerigen/botol bersih; c) Masukan hidrogen peroksida ke dalam jerigen/botol berisi alkohol; d) Selanjutnya, masukan gliserin ke dalam jerigen/botol. Perlu diperhatikan bahwa cairan gliserin lengket dan kental, jadi pastikan jangan ada yang tertinggal di gelas ukur dengan cara membilasnya dengan air suling; e) Setelah semua bahan terkumpul dalam jerigen/botol tambahkan air suling hingga mencapai 1 liter; f) Segera tutup jerigen/botol setelah semua bahan dimasukan untuk menghindari menguapnya alkohol; g) Campurkan semua bahan dengan cara mengocok jerigen/botol dengan perlahan hingga dapat dipastikan semua bahan tercampur rata; h) Segera bagikan campuran hand sanitizer ke dalam botol yang 
lebih kecil agar mudah untuk digunakan; i) Simpan botol-botol tersebut selama 72 jam untuk memastikan tidak ada kontaminasi mikroorganisme dari wadah botol; dan j) Hand sanitizer siap digunakan.

\section{a. Pencapaian Program}

Program ini berjalan dengan lancar atas dukungan masyarakat desa kelurahan Uepai. Dukungan juga bersumber dari pemerintah daerah setempat yang mengizinkan Peserta KKN Tematik bersama masyarakat. Secara Jangka Pendek : Meningkatkan pemahaman dan kemampuan warga masyarakat dalam membuat handsanitiser sendiri dengan bahan-bahan yang ada disekitar mereka sebagai bagian dalam penanggulangan Covid 19. Secara Jangka Panjang : Menanamkan pemahaman dan perhatian masyarakat dalam membiasakan menggunakan handsanitiser dengan benar sebagai bagian dalam penanggulangan Covid 19 dalam kehidupan sehari hari.

\section{b. Kendala}

Kendala yang dihadapai dalam program pembuatan handsanitiser sendiri dengan bahan-bahan yang ada, masih ada sebagain masyarakat yang belum berperan aktif dalam mengikuti setiap tahapannya. Hal ini disebabkan karena pemahaman masyarakat tentang pentingnya menggunakan handsanitiser sendiri dengan bahan-bahan yang ada disekitar masih kuran dan sosialisasi penanggulangan Covid 19 belum dilaksanakan secara menyeluruh dan berkesinambungan.

\section{Tindak Lanjut}

Perlu kontrol dari pihak pemerintah setempat dalam penanaman pemahanan tentang pentingnya menggunakan handsanitiser sendiri dengan bahan-bahan yang ada di sekitar sesuai dengan protokol kesehatan sebagai salah satu cara penanggulangan Covid 19. Pemerintah Desa/Kelurahan dapat pula melanjutkan dan meningkatkan program ini bagi warga dilingkungan masing-masing.

\section{Membantu Pemerintah Daerah dalam Pembagian Bantuan}


Pemerintah menggelontorkan berbagai skema bantuan untuk membantu masyarakat selama pandemi Covid-19. Dana triliunan rupiah itu dikucurkan untuk program jaring pengaman sosial. Berbagai bantuan ini diharapkan bisa meringankan beban masyarakat yang ekonominya terdampak pandemi.

Selain itu, bantuan ini diharapkan kembali bisa mendongkrak perekonomian yang tumbuh minus 5,32 persen pada kuartal II 2020. Bantuan-bantuan tersebut berupa:

a. Bantuan sembako: Bantuan sosial berupa paket sembako dikucurkan sejak awal pandemi Covid-19 terjadi di Indonesia pada Maret.

b. Bantuan sosial tunai: Sama dengan bantuan sembako, program ini juga dikucurkan sejak awal kasus Covid-19 muncul di Indonesia. Bedanya, bantuan tunai ini menyasar warga di luar Jabodetabek. Program ini memberikan dana secara tunai sebesar Rp 600.000 kepada masyarakat selama 3 bulan, yakni April, Mei, dan Juni.

c. BLT dana desa: Pemerintah juga mengalihkan sebagian anggaran dana desa untuk BLT ini demi mengahadapi dampak ekonomi pandemi Covid-19. BLT Dana Desa disalurkan dalam dua gelombang. Masing-masing gelombang terdiri dari tiga tahapan. Gelombang pertama diberikan pada bulan April (tahap I), Mei (tahap II), dan Juni (tahap (III). Per bulannya, masing-masing keluarga penerima manfaat (KPM) akan mendapatkan bantuan sebesar Rp 600.000.

d. Listrik gratis; Pemerintah juga memberikan insentif tarif listrik pelanggan yang terdampak pandemi Covid-19.

e. Kartu Prakerja: Kartu Prakerja dirilis pemerintah untuk membantu karyawan yang terkena PHK dan pengangguran. Peserta dari program ini akan mendapatkan bantuan insentif untuk pelatihan kerja sebesar Rp 1 juta per bulannya.

f. Subsidi gaji karyawan: Baru-baru ini, pemerintah memutuskan mengucurkan bantuan subsidi gaji bagi karyawan swasta. Karyawan yang mendapat subsidi ini adalah mereka yang terdaftar di BPJS Ketenagakerjaan dengan gaji di bawah Rp 5 juta. 
g. BLT usaha mikro kecil: Terakhir, pemerintah mengucurkan bantuan para pelaku usaha mikro kecil berupa dana hibah atau bantuan langsung tunai (BLT). Skemanya, yakni kucuran bantuan modal usaha Rp 2,4 juta yang ditransfer lewat rekening.

Pada pelaksanaan KKN Tematik berkaiatan dengan kegiatan bersama pemerintah dalam menyalurkan bantuan pemerintah pusat.

\section{a. Pencapaian Program}

Program ini berjalan dengan lancar pada setiap lokasi yang berdeda. Hal ini disebabkan karena dukungan warga dan pemerintah daerah setempat. Secara Jangka Pendek : Meningkatkan penemuhan kebutuhan pokok sebagai upaya pemberdayaan masyarakat dalam menghadapi penanggulangan Covid 19 melalui. Secara Jangka Panjang : Menanamkan semangat dan kepedulian masyarakat dalam memenuhiu kebutuhan hidupnya dalam upaya penanggulangan Covid 19 dalam kehidupan sehari hari.

\section{b. Kendala}

Kendala yang dihadapai dalam program penyaluran bantuan, masih ada sebagain masyarakat yang tidak mengindahkan aturan untuk tetap antri sesuai dengan waktu yang telah ditetapkan. Hal ini disebabkan karena pemahaman masyarakat tentang pentingnya mengikuti arahan untuk tetap disiplin dalan menerima bantuan masih kuran.

\section{c. Tindak Lanjut}

Perlu kontrol dari pihak pemerintah setempat dalam penanaman pemahanan tentang pentingnya saling menghargai satu sama lain dan menjaga ketertiban antar warga masyarakat khusunya dalam penerimaan bantuan dari pemerintah. Pemerintah Desa/Kelurahan dapat pula melanjutkan dan meningkatkan program ini bagi warga dilingkungan masing-masing dengan tetap memperhatikan protokol kesehatan. 


\section{Penutup}

Pelaksanaan Kuliah Kerja Nyata (KKN) Tematik Covid 19 tahun 2020 di Kota Kendari, Kab. Konawe, Kab. Konawe Selatan, dan Kab. Muna berjalan dengan baik dan lancar. Program yang telah dilaksanakan meliputi 8 bidang kegiatan ( Sosialisasi pencegahan Covid-19, Penyemprotan cairan disenfektan, Pembuatan jamu dan Teh Kelor, Pembuatan masker, Pembagian masker, Pembuatan medi/alat cuci tangan, Pembuatan handsanitiser, dan Penyaluran bantuan terhadap warga terdampak covid-19) sesuai dengan tujuan pelaksanaan KKN tematik Penaggulangan Covid-19. Partisipasi dan dukungan masyarakat cukup tinggi, dimana masyarakat turut aktif dalam pelaksanaan program sehingga masyarakat dapat mengambil manfaatnya dengan lebih maksimal. Walaupun Program KKN Tematik Covid-19 berjalan secara lancar, namun ada beberapa kendala dan hambatan dalam pelaksanaan program, seperti susahnya mengumpulkan masyarakat ketika sosialisasi, cuaca yang tidak mendukung serta persiapan yang kurang ketika program dilaksanakan. Berbagai program kerja dalam KKN tematik Covid-19 ini semoga dapat memberikan banyak manfaat bagi mahasiswa KKN dan warga Desa/Kelurahan di Empat kabupaten/Kota di Sulawesi Tenggara.

\section{Daftar Pustaka}

Bramasta, D. B. (2020). Sering Disebut-sebut, Apa Itu New Normal? Retrieved from https://www.kompas.com/tren/read/2020/05/16/164600865/seringdisebutsebut-apa-itu-new-normal-?page=all.

Kemenkes RI. (2020). Himbauan tentang Upaya Pencegahan Penularan Covid-19 di Tempat Kerja. [Online] tersedia pada: https://dinkes.kedirikab.go.id/konten/uu/26297-Himbauan-Kemenkescovid19.pdf.

Keputusan Menteri Kesehatan Republik Indonesia Nomor Hk.01.07/Menkes/413/2020 Tentang Pedoman Pencegahan Dan Pengendalian Coronavirus Disease 2019 (Covid-19)

Satgas COVID-19 RI (2020). Infografis COVID-19 (10 Juli 2020. [Online] tersedia pada https://covid19.go.id/p/berita/infografis-covid-19-10-juli-2020. 
Satgas Covid-19 Sultra. (2020). Data Jumat 10 Juli 2020 Pukul 17.00 WITA. Diakses pada tanggal 12 Juli 2020. [Online] tersedia pada:

ttps://www.facebook.com/satgascovid19sultra/photos/pcb.161959072115885/1 6 1959032115889/?type=3\&theatre.

Soegiharto, dkk. 2019. Model Kuliah Kerja Nyata (KKN) Tematik desa Membangun. Jakarta: Pusat Penelitian Dan Pengembangan Badan Penelitian dan Pengembangan, Pendidikan dan Pelatihan dan Informasi Kementerian Desa Pembangunan Daerah Tertinggal Dan Transmigrasi

Sumber: https://mediaindonesia.com/read/detail/298663-efektifkah-penyemprotandisinfektan-untuk-atasi-covid-19

Universitas Halu Oleo. 2020. Petunjuk Pelaksanaan KKN Tematik Covid-19.

WHO. (2020). Coronavirus disease (COVID -19) Pandemic. [Online] tersedia pada: https://www.who.int/emergencies/diseases/novel-coronavirus-2019 